\title{
The effects on human health of non-metallic, semimetals and heavy metals compounds generated by mining activities along the Serbian-Romanian border
}

Review

\author{
BIANCA-VANESA BOROS ${ }^{1}$, DIANA-LARISA ROMAN ${ }^{1}$, VASILE OSTAFE ${ }^{1}$, RADMILA \\ MARKOVIĆ $^{2}$, VOJKA GARDIĆ ${ }^{2}$, ZORAN STEVANOVIĆ $^{2}$, ADRIANA ISVORAN $^{1 *}$
}

${ }^{I}$ Department of Biology-Chemistry and Advanced Environmental Research Laboratories, West University of Timisoara, 300223, Timisoara, Romania

${ }^{2}$ Mining and Metallurgy Institute, Bor, Republic of Serbia

*Corresponding author: adriana.isvoran@e-uvt.ro

$\begin{array}{lll}\text { Received: } & \text { Accepted: } & \text { Published: } \\ \text { 14.06.2021 } & 22.06 .2021 & 25.06 .2021\end{array}$

\begin{abstract}
This study makes an overview of the chemical pollutants, such as Be and its compounds, $S$ and its compounds, $\mathrm{P}$ and its compounds, chlorine and chlorides, $\mathrm{Na}_{2} \mathrm{O}, \mathrm{K}_{2} \mathrm{O}, \mathrm{Ti}_{2} \mathrm{O}, \mathrm{CaO}, \mathrm{MgO}, \mathrm{CuO}, \mathrm{SiO}_{2}, \mathrm{Al}_{2} \mathrm{O}_{3}$, $\mathrm{Fe}_{2} \mathrm{O}_{3}, \mathrm{Cr}_{2} \mathrm{O}_{3}, \mathrm{As}_{2} \mathrm{O}_{3}$, that were registered in the mining operations areas in the cross-border region of Romania and Serbia. In addition, their possible effects on human health were discussed. Among the oxides, $\mathrm{SiO}_{2}, \mathrm{Al}_{2} \mathrm{O}_{3}, \mathrm{Fe}_{2} \mathrm{O}_{3}$ are the most abundant. From all these pollutants, the most health effects were registered for the compounds of $P, S$ and $C a$ and the lowest number of health effects was recorded for chlorine. Among the human health effects that have been observed for these compounds, the most common are related to skin, eye and respiratory irritations in the case of acute exposure, but chronic exposure may lead to diseases affecting all the human organs. This information is important for population living in this area, due to air, water and soil pollution, but especially for professional exposure as workers in the mining operations are exposed to higher concentrations of pollutants and for long time.
\end{abstract}

Keywords: chemical pollutants, copper mining, human health risks

\section{INTRODUCTION}

Mining and mineral processing has played a vital role in the history and economy in the Western Romania and Eastern Serbia. Mining the polymetallic ores, jointly with the metal extraction process exist in these countries for over one hundred years being, before 1990, among the powerful industrial sectors and the main European source of copper, lead and zinc. The requirement of these metals for industrial activities will increase and an attempt to stop the mining activities in order to reduce the pollution is not the available solution. Moreover, the situation of the mining dump in Moldova Noua (Romania) emphasizes that environmental pollution did not stop after the cessation of mining activities. Annual reports concerning the state of the environment in Romania illustrate that $32.6 \%$ of rivers from this region present an inferior ecological state and soil is polluted by mining operations. Furthermore, this area is also characterized by air pollution in conditions of strong wind due to the waste deposited in the tailing ponds that cover more than 120 ha [1].

In Serbia, the most important active copper mines are situated in Bor District and generated more than $1.2 \times 10^{9}$ tones of wastes on the total area of 400 ha that contain perilous pollutants, especially $\mathrm{SO}_{2}$ and heavy metals [2]. The mining waste resulting from copper mines situated in Bor District conduct to continuous degradation of the valley of the Bor River causing air, soil and water pollution [3]. 
In 2019, the main air pollutants in the Moldova Noua area, alongside heavy metals, were $\mathrm{SO}_{2}$ (with the annual average of $9.60 \mu \mathrm{g} / \mathrm{m}^{3}$, daily limit value being $125 \mu \mathrm{g} / \mathrm{m}^{3}$ ), airborne particles with the diameter lower than 10 micrometres also known as particulate meter 10 (PM10, $19.83 \mu \mathrm{g} / \mathrm{m}^{3}$, annual limit value being $\left.40 \mu \mathrm{g} / \mathrm{m}^{3}\right)$ and benzene $\left(2.47 \mu \mathrm{g} / \mathrm{m}^{3}\right.$, annual limit value being $\left.5 \mu \mathrm{g} / \mathrm{m}^{3}\right)$ [4]. Among these pollutants, in Serbia, $\mathrm{SO}_{2}$ may results from copper mineralization that is mostly porphyry type of deposits and contains mostly sulphur minerals associated with pyrites, one of the main sulphuric acid generators in contact with atmosphere [5]. In Romania, because the mining operations are stopped, $\mathrm{SO}_{2}$ may result from electric plants based on fossil fuel. Acid rain results from the combination of rain and $\mathrm{SO}_{2}$ and causes damage to crops, trees and buildings not only in the regions of mining activities, but also at great distances from it.

Various pollutants have been registered in wastes generated by mining activities in the cross border region of Romania and Serbia. Sulphur, $\mathrm{CaO}$ and $\mathrm{SiO}_{2}$ have been identified in sterile samples from Moldova Noua, the mass percentages of their mean content being $1.42 \%$ for $\mathrm{S}, 13.03 \%$ for $\mathrm{CaO}$ and $31.89 \%$ for $\mathrm{SiO}_{2}$ [6]. Another study assessed the chemical composition of mining waste samples collected from the tailing pond in Moldova Noua [7]. It proved the presence in the minerals of the mining waste of chlorine compounds in a mass percentage of $0.048 \%$ and of several oxides: $\mathrm{SiO}_{2}$ (55.42\%), $\mathrm{Al}_{2} \mathrm{O}_{3}$ (14.98\%), $\mathrm{Fe}_{2} \mathrm{O}_{3}$ (8.44\%), $\mathrm{SO}_{3}$ (9.089\%), $\mathrm{CaO}(6.08 \%), \mathrm{MgO}(2.31 \%), \mathrm{K}_{2} \mathrm{O}$ (1.91\%), $\mathrm{Ti}_{2} \mathrm{O}(0.74 \%), \mathrm{Na}_{2} \mathrm{O}(0.73 \%), \mathrm{P}_{2} \mathrm{O}_{5}(0.231 \%), \mathrm{CuO}(0.112 \%), \mathrm{Cr}_{2} \mathrm{O}_{3}(0.062 \%), \mathrm{MnO}$ $(0.054 \%), \mathrm{As}_{2} \mathrm{O}_{3}(0.043 \%)$ [7]. Quite similar oxides have been registred in the long-term stored rock waste produces by Gradir mine (Montenegro) that assures the exploitation of lead and zinc: $\mathrm{SiO}_{2}(54.5 \%), \mathrm{Al}_{2} \mathrm{O}_{3}(16.2 \%), \mathrm{Fe}_{2} \mathrm{O}_{3}(8.22 \%), \mathrm{K}_{2} \mathrm{O}$ (7.5\%), $\mathrm{SO}_{3}$ (7.05\%), $\mathrm{MgO}$ (2.41\%), $\mathrm{CaO}$ (0.92\%), $\mathrm{TiO}_{2}(0.6 \%), \mathrm{MnO}(0.34 \%), \mathrm{Na}_{2} \mathrm{O}(0.31 \%), \mathrm{P}_{2} \mathrm{O}_{5}(0.12 \%)$ [8]. Several oxides were also found in the mining-waste (tailing ponds, mine tailing, waste dump) samples from an iron ore mine operating in the district of Jerantut (Malaysia): $\mathrm{Fe}_{2} \mathrm{O}_{3}(39.58-62.95 \%), \mathrm{SiO}_{2}(14.05-34.97 \%), \mathrm{CaO}$ $(7.19-15.24 \%), \mathrm{MgO}(1.32-6.75 \%), \mathrm{K}_{2} \mathrm{O}$ (0.97-5.31\%), $\mathrm{TiO}_{2}(0.86-1.79 \%)$ and $\mathrm{SO}_{3}(1.09-$ $3.95 \%$ ) [9]. These data reveal that these oxides are commonly found in the mine-waste samples and also illustrate the potential of mining waste to participate to mineral carbonation reactions. Usually the metal oxides are alkaline, aluminium, iron, cromium, arsenic and titanium oxides are amphoteric, but silicon, phosphorus and sulphur oxides are acidic. These properties strongly contributes to their effects on the human health and on the environment.

Not al last, the rain water in the region of Moldova Noua, in the period 2016-2019, proved to be abundant in $\mathrm{Cl}^{-}(160.72 \mu \mathrm{g} / \mathrm{L}), \mathrm{SO}_{4}{ }^{2-}(240.91 \mu \mathrm{g} / \mathrm{L}), \mathrm{Ca}^{2+}(367.31 \mu \mathrm{g} / \mathrm{L})$ and $\mathrm{Mg}^{2+}(219.42 \mu \mathrm{g} / \mathrm{L})$ because of the contribution of soil dust from the mining activities [10], illustrating the high risk of contamination in case of ingestion. Other study highlighted that the tailing ponds from this area represent a source of pollution due to the drying of the pond and the action of the Cosava wind, which lead to the formation of soil dust containing sterile sand and conducting to high risk of contamination by inhalation [11].

In the waste waters generated by the Bor copper mine, besides heavy metals, the following pollutants have been identified: Be $(0.003 \mathrm{mg} / \mathrm{L}-0.074 \mathrm{mg} / \mathrm{L}$, the allowed value being 0.0002 $\mathrm{mg} / \mathrm{L}), \mathrm{Mg}^{2+}(>670 \mathrm{mg} / \mathrm{L})$, sulphate $(132.51 \mathrm{mg} / \mathrm{L}-4145.45 \mathrm{mg} / \mathrm{L})$, phosphate $(0.05 \mathrm{mg} / \mathrm{L}-1.34$ $\mathrm{mg} / \mathrm{L})$ and chloride $(22.14 \mathrm{mg} / \mathrm{L}-184.09 \mathrm{mg} / \mathrm{L})[12,13]$. The average oxides content in the Bor flotation tailing were $0.8 \%$ [14].

The main pollutants, alongside heavy metals, identified in the mining areas of Moldova Noua and Bor are presented in the figure 1. 


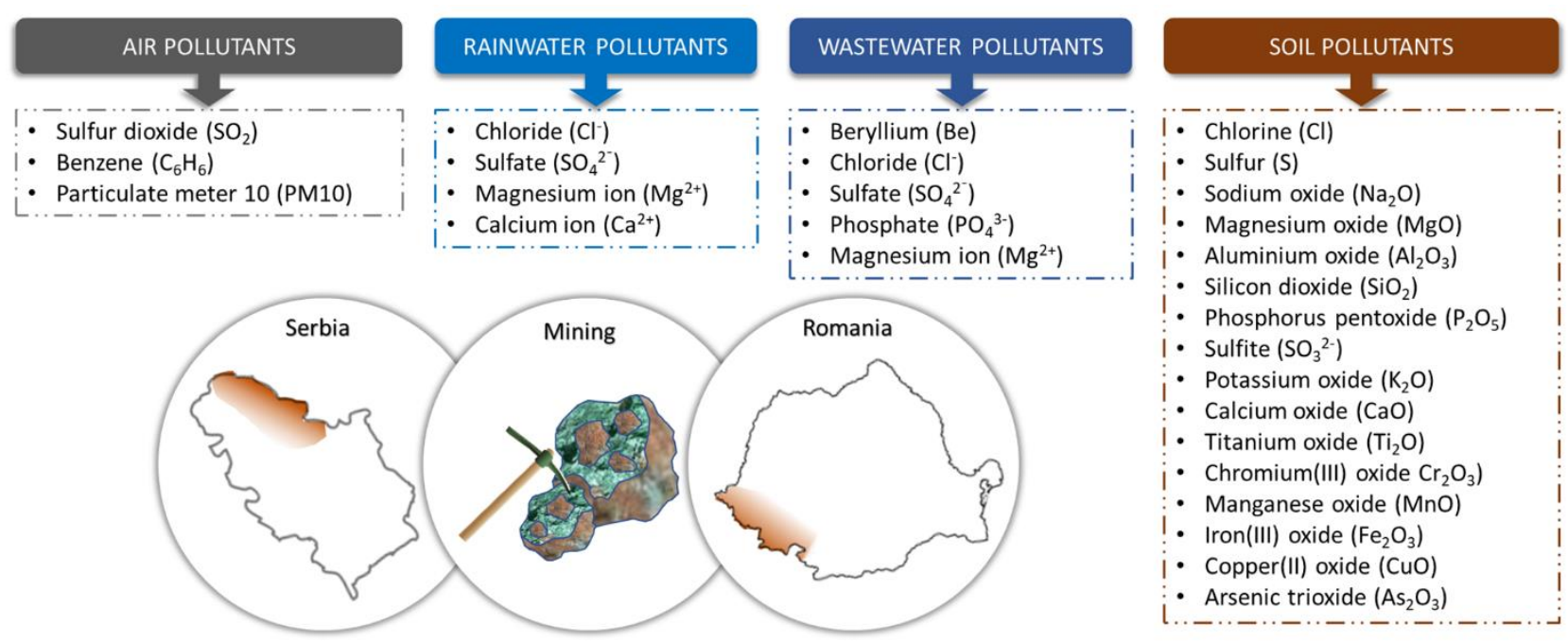

Fig. 1. Elements whose compounds have been identified in the mining areas of Moldova Noua (Romania) and Bor (Serbia) according to the available data

Quality of life is strictly correlated and dependent on air, water and soil quality. The mining sites represent important pollution sources with negative effects on the environment and mostly on human health due to the diverse exposure routes and the toxic effects of the mining pollutants. The routes of the human exposure to pollutants produced by mining activities are ingestion, inhalation and dermal exposure, every route conducting to distinct health effects. This review makes an overview of the human health effects produced by other pollutants than the heavy metals resulting from mining activities in the cross border region of Romania and Serbia. We have considered information obtained from humans and also from animal experiments due to the fact that data regarding the effects of these pollutants on the humans are scarce. To the best of our knowledge, this issue has not been addressed in other studies. This information becomes important especially for professional exposure, but also for accidental exposure of people living in these areas.

\section{DISCUSSIONS}

\section{Effects of beryllium and its compounds on human health}

Beryllium $(\mathrm{Be})$ is found in nature in the composition of minerals. The toxicokinetics of $\mathrm{Be}$ and of its compounds are not well studied, although Be has been found in the lungs and urine of individuals with non-occupational exposure [15]. Professionals working in industries where beryllium is present may be exposed by inhaling or contacting beryllium in the air or on surfaces. The absorption of $\mathrm{Be}$ is primarily via the lungs, the deposited Be moving exceedingly slow into the pulmonary blood circulation. The entrance of Be into the organism can also occur by swallowing. Once swallowed, less than $1 \%$ is absorbed into the gastrointestinal capillaries, becoming proteinbound and being deposited for a long period in the liver, spleen and skeleton [16]. The elimination of the absorbed Be occurs primarily in urine, while unabsorbed Be is eliminated via faeces [15]. Acute beryllium disease (ABD) has been observed in humans after single massive exposure, while the exposure to lower concentrations may lead to chronic beryllium disease (CBD) in $1-5 \%$ of exposed individuals [15]. CBD affects predominantly the lungs but it may also produce skin sensitization, an immunological response to beryllium as beryllium - specific proliferation [17]. The dermal exposure to soluble beryllium compounds leads to a cell-mediated hypersensitivity of the skin [15]. Be and its compounds are classified in the European community as known animal carcinogens suspected to be human carcinogens [18].

Animal studies have shown that the inhalation of Be particles leads to their presence in the lungs for several years, lung cancer being significantly increased by inhalation of Be. The continuous inhalation of Be produces hyperplasia, metaplasia, pneumonitis or fibrosis [15]. Soluble beryllium compounds administered orally as single doses were moderately toxic, but chronical dietary 
exposure of dogs to soluble beryllium sulphate has led to gastrointestinal lesions and bone marrow hypoplasia. Similarly, the chronical dietary exposure of rats to sparingly soluble beryllium carbonate lead to skeletal disorder, a possible cause being the decrease of gastrointestinal absorption of phosphorus as insoluble beryllium sulphate was formed in the intestine [15]. The exposure of female rats to beryllium nitrate resulted in severe alterations of some biochemical parameters: glycogen content, alkaline phosphatase, adenosine triphosphatase and succinic dehydrogenase activities decreased significantly after the beryllium treatment, the activity of glucose-6phosphatase and acid phosphatase, as well as the hepatic lipid peroxidation level were increased [19].

\section{Effects of sulphur compounds on human health}

One of the natural sources of sulphur is represented by subterranean deposits in the form of metallic sulphides which are present in copper mines [20]. Sulphur is essential to the entire biological kingdom due to its incorporation in various molecules and has many functions: free radical scavenging, protein stabilization and synthesis, regulation of gene expression, DNA methylation and repair, metal transport, remodeling of the extracellular matrix components, tissue integrity and protection. It is used in wound healing, in dermatologic issues and in acute exposure to radioactive materials [21]. Although groundwater can naturally contain sulphates, their high levels can have acute and chronic effects on human health [22]. Gastrointestinal effects of sulphate on human health have been reported [22-24].

Inhalation of sulphur dioxide is toxic and can be very dangerous in high concentrations. Furthermore, long-term exposure to low concentrations can also be problematic and was associated with preterm birth [25]. It is known as an eye and respiratory tract irritant, persons with asthma, subnormal pulmonary functions or cardiovascular disease being at a greater risk [26].

Sulphuric acid, being part of AMD, and even of polluted water streams in which the AMD is flowing into, exhibits negative effects on human health. The water containing sulphuric acid could accidentally be ingested or it could come in contact with the skin and produces burns of tissues [27]. The effects of sulphuric acid to the eyes might be blindness, keratitis, cataracts and corneal opacity. In the case of the ears, chondritis and ear drum perforation might occur, while in the case of the nose, nostril stenosis might be caused [27]. The fatal dosage of sulphuric acid ingestion is 3.5-7.0 $\mathrm{mL}$, the mortality being high, with a recovery rate of only $35 \%$ [28]. Ingestion of sulphuric acid also causes nausea and vomiting and severe pain in the mouth, chest and abdomen. Perforations in the esophagus might occur, ultimately leading to death due to cardiovascular collapse and shock. The contact of sulphuric acid with glottic structures leads to choking and aging [27]. The inhalation of sulphuric acid vapors can cause coughing, bronchoconstriction, and in prolonged exposure, proximal and distal airway injury [28]. Sulphuric acid fumes might also cause erosion of teeth in long term exposure, as well as an increase in the prevalence of periodontal pockets [29]. In vivo experimental data on rats and mice show that sulphuric acid might act as a weak, locally acting chemical carcinogen [30]. At room temperature, pure sulphur trioxide is injurious to the eyes, skin and mucosa [31]. When inhaled, it is rapidly converted to sulphuric acid in the respiratory tract, leading to a change in the $\mathrm{pH}$ of the mucus that may lead on adverse effects on health [32].

\section{Effects of phosphorus compounds on human health}

Phosphorus (P) is essential for life since it is part of DNA and ATP, but it is also one of the most toxic substances, being used as pesticide [33]. Phosphorus pentoxide is the most common oxide of phosphorus that acts as an irritant of the eyes, mucous membrane of the respiratory tract and of the lungs, with a 1-hour $\mathrm{LC}_{50}$ of $1.22 \mathrm{mg} / \mathrm{m}^{3}$ [34]. The effects of inhaling phosphorus pentoxide include irritation of the nose and throat, leading to labored breathing, chemical pneumonitis and possibly to lung edema [35]. Both inhalation and skin contact cause the hemolysis of the erythrocytes, as well as dysfunction of multiple organs [34]. Phosphorus pentoxide acts as a corrosive when ingested. On contact with moisture it generates heat and burns the mucous surfaces. Symptoms include sore throat, staining of the peribucal area with yellow or brown, nausea, vomiting, abdominal pain and 
diarrhea, possibly leading to death [35]. It is also a corrosive substance towards the skin, redness, severe irritation, pain and burns can be observed. Chronic exposure to phosphorus pentoxide via ingestion or inhalation leads to systemic phosphorus poisoning, resulting in jaw and tooth abnormalities, liver damage, blood disorders, cardiovascular effects and kidney damage [33].

Human and animal studies have revealed the toxic effects of phosphate in hastening various pathologies, from vascular calcification to tumors formation and aging. Acute phosphate toxicity is relatively rare, but it can produce hypocalcaemia, tetany, hypotension and tachycardia. Chronic phosphate toxicity can lead to the deposition of calcium phosphate crystals in tissues, including cardiovascular calcification that is a fatal disease [36].

\section{Effects of chlorine and chloride on human health}

Chlorineis one of the most common substances involved in toxic inhalation. The chlorine inhalation and its permeation of the respiratory tract cause damage to both airways and alveoli, hypoxia, asphyxia, free oxygen radicals, increased sympathetic activity, respiratory failure, pulmonary hypertension, vascular congestion and edema, cardiomegaly, acute burns of upper and proximal airways, etc. [37, 38]. The mechanism underlying the toxicity of chlorine is related to its solubility in water-based environments. When inhaled, $\mathrm{Cl}$ forms hydrochloric and hypochlorous acids. It also leads to ionization, the ions being able to cross the cell membrane, leading to the formation of oxygen free radicals [39]. Prolonged exposure to high levels of chlorides may lead to diarrhea, nausea, inflammatory bowel disease [40].

\section{Effects of sodium oxide $\left(\mathrm{Na}_{2} \mathrm{O}\right)$ on human health}

The effects of sodium oxide in combination with sodium silicate were analyzed on male Sprague Dawley rats. The mixture with different ratios and concentrations were administered by gastric intubation. In the highest dose group $(4640 \mathrm{mg} / \mathrm{kg}$ ), rats had symptoms such acute depression, nasal discharge, dyspnea and gasping, leading to death, with post-mortem analysis revealing gastrointestinal hemorrhage and congestion of the kidneys, liver, heart and lungs. In the lowest dose group $(464 \mathrm{mg} / \mathrm{kg})$, no apparent toxic effects were observed, while in the other two dose groups (1000 and $2150 \mathrm{mg} / \mathrm{kg}$ ) rats showed gasping, dyspnea and acute depression [41].

The skin irritation effects of sodium oxide in combination with sodium silicate in two ratios (2.0 and 2.4 sodium silicate to 1.0 sodium oxide) have been tested in rabbits. The 2.0 ratio material was classified as severe irritant, while the 2.4 ratio material was classified as a moderate irritant. Their acute dermal toxicity was also studied utilizing New Zealand white rabbits. After 14 days from exposure, through the closely clipped intact abdominal skin, effects such as severe, irreversible erythema and edema at the test site were observed for the 2.0 ratio material. The 2.4 ratio material caused moderate, reversible irritation at the test site [42].

\section{Effects of potassium oxide $\left(\mathrm{K}_{2} \mathrm{O}\right)$ on human health}

Potassium is an essential element, its equilibrium between the intercellular and extracellular medium being maintained by several homeostatic mechanisms, those disturbance leads to hypokalemia or hyperkalemia [43]. The inhalation of potassium oxide leads to sore throat, cough, burning sensation, shortness of breath and labored breathing, as well as burning sensation in throat and chest, shock and collapse. Its contact with the skin causes redness, pain, irritation and serious skin burns [44].

\section{Effects of titanium oxide $\left(\mathrm{Ti}_{2} \mathrm{O}\right)$ on human health}

We could not identify titanium oxide effects on the human health in specific literature.

\section{Effects of calcium oxide ( $\mathrm{CaO}$ ) on human health}

Calcium is one of the most important cations in the organism, but it can impair health if the intake quantity is inadequate. The ingestion of calcium oxide can lead to swelling of the lips, to erosion of the oral cavity, swelling of the buccal mucosa, redness of the palate, erosion of the antrum of the 
stomach and ulcer in the duodenal bulb [45]. Due to its alkalinity and exothermic reaction with water, calcium oxide has an irritant action. Due to its causticity to skin, cornea, conjunctiva and the mucous membranes of the upper respiratory tract, calcium oxide can cause dermatitis, ulcers, chemical burns with desquamation, urticaria, conjunctival irritation, spasmodic blinking, lacrimation, ocular perforation, ulceration and inflammation of the respiratory passages [46]. Experimental data showed that the calcium oxide dust produced an chemestethic effect with the increase of nasal secretion from before to after exposure, supraglottic and infraglottic edema [47, 48].

\section{Effects of magnesium oxide $(\mathrm{MgO})$ on human health}

Magnesium oxide has several medical uses: supplements for increasing bone mineral content [49], laxative [50], possible use for inhibition of crystallization of calcium oxalate stones in combination with potassium-sodium citrate [51]. It can also have negative effects on health leading to hypermagnesemia. The oral administration of magnesium oxide microparticles to female Wistar rats lead to reduction in body weight gain, feed intake and organ weight profile. The hematological results revealed that rats treated with $\mathrm{MgO}$ microparticles showed reduced levels of hemoglobin, red blood cells, platelet and hematocrit, white blood cells levels were elevated [52].

\section{Effects of copper oxide $(\mathrm{CuO})$ on human health}

Safety Data Sheet for copper oxide illustrate that this compound can produce eye irritations, may cause respiratory tract irritation if inhaled, skin irritations and it can be toxic by ingestion [53]. Some published data emphasize that products impregnated with copper oxide particles are safe and do not cause skin irritations and that this oxide can be used in would healing processes [54].

\section{Effects of manganese oxide ( $\mathrm{MnO})$ on human health}

Acute exposure to manganese oxide may lead to eyes, skin and respiratory system irritations. Longterm exposure to dust containing high concentration of $\mathrm{MnO}$ may produce pneumoconiosis [55].

\section{Effects of silicon dioxide $\left(\mathrm{SiO}_{2}\right)$ on human health}

The inhalation of fine particulate silicon dioxide (silica) leads silicosis, an irreversible, potentially fatal, fibrotic lung disease characterized by lysosomal damage due to the phagocytosis of crystalline silica [56]. Other effects include the development of pulmonary silicoproteinosis due to the accumulation of eosinophilic proteinaceous material in the pulmonary alveolar spaces. In some cases, cancer, tuberculosis, autoimmune disease, progressive systemic sclerosis, rheumatoid arthritis, systemic lupus erythematosus, glomerulonephritis or vasculitis, might be associated with silicosis [57-59]. The patients exposed to silica showed glomerular and tubular lesions and Si was present in kidney tissue [8]. Silica exposure might lead to autoimmunity as silica causes activation of innate immune system, resulting in the production of proinflammatory cytokines, adaptive immunity activation, tolerance breaking and formation of autoantibodies which leads to renal damage [60].

\section{Effects of aluminum oxide $\left(\mathrm{Al}_{2} \mathrm{O}_{3}\right)$ on human health}

Both acute and long-term exposure to aluminum oxide may produce mild skin irritation, irritation and redness in the case of eye contact, respiratory system irritation in the case of inhalation, irritation of the throat in the case of ingestion [61].

\section{Effects of ferric oxide $\left(\mathrm{Fe}_{2} \mathrm{O}_{3}\right)$ on human health}

Dust containing ferric oxide $\left(\mathrm{Fe}_{2} \mathrm{O}_{3}\right)$ may cause eye and/or respiratory tract irritation from mechanical abrasion and repeated exposure to iron oxide dust may cause metal fever. Prolonged or repeated eye contact with this substance may cause permanent iron staining of the eyes [62]. 


\section{Effects of chromic oxide $\left(\mathrm{Cr}_{2} \mathrm{O}_{3}\right)$ on human health}

Chromic oxide is recognized as a hazardous substance for humans. Eye and skin contact may lead to irritations, dust containing chromic oxide may cause mechanical irritation. Long term exposure to chromic oxide may conduct to skin allergies, sensitization dermatitis and possible ulcerations, and repeated inhalation may cause chronic bronchitis $[63,64]$.

\section{Effects of arsenic trioxide $\left(\mathrm{As}_{2} \mathrm{O}_{3}\right)$ on human health}

Even if this compound has medical applications in treating cancer, its poisonous effects are wide and well known. Common side effects of arsenic trioxide include shortness of breath, and headaches.

In the case of acute ingestion, there are digestive diseases: vomiting, abdominal pains, diarrhea. Ingestion of high doses of this compound can lead to convulsions, cardiotoxicity, liver and kidneys toxicity. Arsenic trioxide is dangerous on contact with the eyes even in the case of dilute solutions [65]. Other side effects of arsenic trioxide are: peripheral neuropathy, perforations of nasal septa, skin effects (pigmentation, dermatitis, warts), encephalopathy, increased glycosylated hemoglobin, increased systolic blood pressure, increased vasospastic reactivity in the fingers. It may also induces oxidative DNA damage in exposed humans. In addition, occupational inhalation exposure to arsenic trioxide leads to increased incidences of lung cancer [66].

\section{Overview of the human health effects of the mining pollutants, alongside heavy metals}

The overall effects of the mining pollutants, alongside heavy metals, belong to the following categories: respiratory, cardiovascular, gastrointestinal, skin irritation, eye irritation and sometimes carcinogenicity. From all the discussed pollutants, the compounds of $\mathrm{P}, \mathrm{S}$ and $\mathrm{Ca}$ had the most effects from different categories (figure 2a). The lowest number of effects from different categories was observed for chlorine and chlorides.

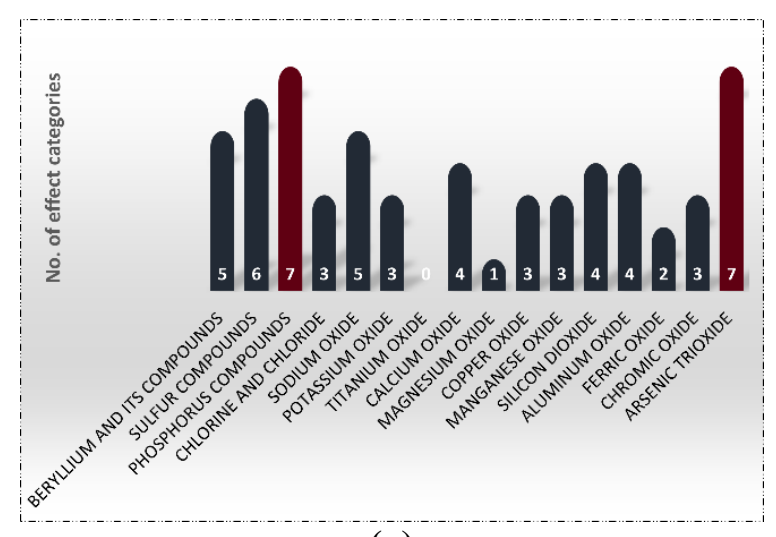

(a)

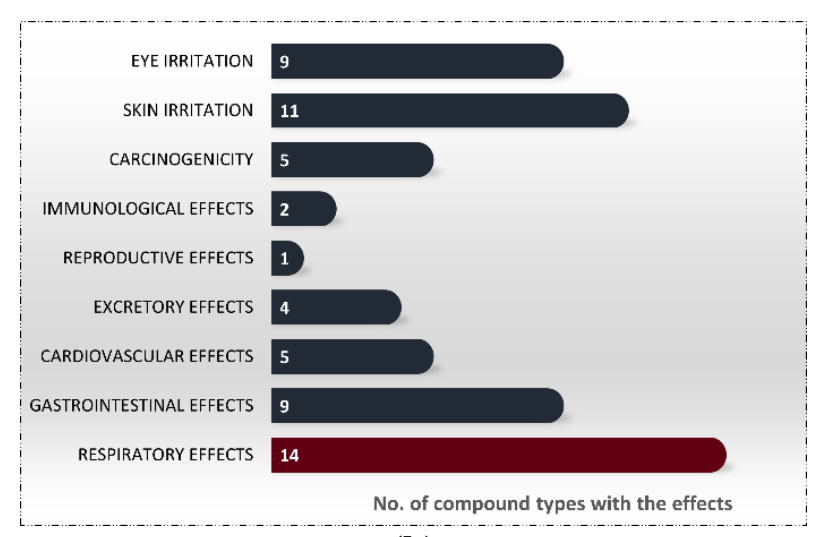

(b)

Fig. 2. (a) Number of effect categories caused by the compounds of each described element; (b) Number of pollutants that cause effects from each observed category.

The most common category of effects was the respiratory effects, which occurred for all the described elements (figure $2 b$ ).

\section{CONCLUSIONS}

Scientific literature data reveal that there are pollutants, alongside heavy metals, that are found in the mining wastes situated in the cross border region of Romania and Serbia: Be and its compounds, sulphur compounds, phosphorous compounds, chlorine and chlorides, and many oxides: $\mathrm{Na}_{2} \mathrm{O}$, $\mathrm{K}_{2} \mathrm{O}, \mathrm{Ti}_{2} \mathrm{O}, \mathrm{CaO}, \mathrm{MgO}, \mathrm{CuO}, \mathrm{MnO}, \mathrm{SiO}_{2}, \mathrm{Al}_{2} \mathrm{O}_{3}, \mathrm{As}_{2} \mathrm{O}_{3}, \mathrm{Fe}_{2} \mathrm{O}_{3}, \mathrm{Cr}_{2} \mathrm{O}_{3}$. Beside these oxides, $\mathrm{SiO}_{2}$, $\mathrm{Al}_{2} \mathrm{O}_{3}$ and $\mathrm{Fe}_{2} \mathrm{O}_{3}$ were more abundant. More information about the pollution in the cross-border area of Romania and Serbia due to mining activities is publicly available in a knowledge base that we have built [67]. 
Numerous human health effects of these compounds have been already registered, the most common being related to skin, eye and respiratory irritations in the case of acute exposure, but prolonged exposure may lead to serious diseases affecting all the human organs. This information become important because the long time exposure of professionals working in the mining industry and of population living in these areas to air, water and soil pollution with various compounds, including those considered in this study. Taking into account that many of these pollutants have been also registered in the wastes produced by mining of various ores in other countries, the enumerated human health effects apply for all mining areas, not only for the cross border region of Romania and Serbia.

This review is not a pleading for stopping mining activities. Mining industry brings substantial economic growth and benefits to some countries, generating revenues from export and creating jobs. This review advocates the sustainable development of mining activities and rehabilitation of abandoned mines. Current mining practices need to change not only in order to be environmentally acceptable but also to assure social responsibility, i.e. taking proper care of the mine workers and the community around the mine by considering the mining conditions and making them as safe as possible. Abandoned mines must be rehabilitated such as to stop the human health effects and environmental damages. The value of a healthy environment and control of water, air, and soil quality justifies the cost of sustainable development of mining operations.

\section{ACKNOWLEDGEMENTS}

This work was supported by the grant RoRS337, ROmania Serbia NETwork for assessing and disseminating the impact of copper mining activities on water quality in the cross-border area (RoSNET2), in the cadre of Interreg-IPA Cross-border Cooperation Romania-Serbia Programme financed by the European Union under the Instrument for Pre-accession Assistance (IPA II) and cofinanced by the partner states in the Programme.

\section{REFERENCES}

[1] Romanian Agency for Environmental Protection of Caras-Severin County, 2019.

[2] MARKOVIC, Z.S., Sustainability of mining waste in basin Bor, Serbia, Springer, 2012, p. 129136.

[3] DOLD, B., Minerals, 4, no.3, 2014, p. 621.

[4] REPORT on Ambient Air Quality in Caras-Severin County, 2019.

[5] STANOJLOVIĆ, R.D., SOKOLOVIĆ, J.M. , MILOSEVIĆ, N., Environ. Eng. Manag. J., 13, no. 4, 2014 , p. 791.

[6] NITA, L., NITA, S., PANAITESCU, L., MIRCOV, V.D., Proceedings of the $52^{\text {nd }}$ International Scientific Conference "Ecological Agriculture - priorities and perspectives", Lucrari stiintifice, seria Agronomie, 52, 2009, p. 407.

[7] DUMITRU, F.D., DEAK, G., MONCEA, M.A., PANAIT, A.M., MATEI, M., BOBOC, M., LASLO, L., CIOBOTARU, N., LUMINAROIU, L., CORNATEANU, G., GHEORGHE, P.I., AIP Conference Proceedings, 2129, no. 1, 2019, p. 0200681.

[8] RETKA, J., RZEPA, G. , BAJDA, T., DREWNIAK, L., Minerals, 10, no. 12, 2020, p. 1061.

[9] RAMLI, N.A.A., KUSIN, F.M., MOLAHID, V.L.M., Sustainability, 13, no. 4, 2021, p. 1866.

[10] KERESZTESI, A., NITA, I.A., BIRSAN, M.V., BODOR, Z., SZEP, R., Environ. Sci. Pollut. Res., 27, 2020, p. 1.

[11] POPESCU, F., Proc. Tech., 22, 2016, p. 440.

[12] GORGIEVSKI, M., BOZIC, D., STANKOVIC, V., BOGDANOVIC, G., J. Hazard. Mater., 170, no. 2-3, 2009, p. 716.

[13] KORAC, M., KAMBEROVIC, Z., Metalurgija-Journal of Metallurgy, 13, no. 1, 2007, p. 41.

[14] STEVANOVIC, Z.O., ANTONIJEVIC, M.M., BOGDANOVIC, G.D., TRUJIC, V.K., BUGARIN, M.M., Chem. Ecol., 27, no. 5, 2011, p. 401.

[15] BRUCE, R.M., ODIN, M., Beryllium and beryllium compounds, World Health Organization, 2001. 
[16] COOPER, R.G., HARRISON, A.P., Indian. J. Occup. Environ. Med., 13, no. 2, 2009, p. 65.

[17] NEWMAN, L.S., LLOYD, L., DANILOFF, E., Environ. Health. Persp., 104, 1996, p. 937.

[18] STRUPP, C., Ann. Occup. Hyg., 55, no. 1, 2010, p. 43.

[19] SHARMA, P., S. JOHRI, S. SHUKLA, J. Appl. Toxicol., 20, 2000, p. 313.

[20] KOMARNISKY, L.A., CHRISTOPHERSON, R.J., BASU, T.K., Nutrition, 19, no. 1, 2003, p. 54.

[21] HEWLINGS, S., KALMAN, D., EC Nutrition, 14, 2019, p. 785.

[22] DARBI, A., VIRARAGHAVAN, T., JIN, Y.C., BRAUL, L., CORKAL, D., Water. Qual. Res.

J. Can., 38, no. 1, 2003, p. 169.

[23] BACKER, L.C., Crit. Rev. Cl. Lab. Sci., 37, no. 4, 2000, p. 389.

[24] HEIZER, W.D., SANDLER, R.S., SEAL, E., MURRAY, S.C., BUSBY, M.G., SCHLIEBE, B.G., PUSEK, S.N., Dig. Dis. Sci., 42, no. 5, 1997, p. 1055.

[25] SHAH, P.S., BALKHAIR, T., KNOWLEDGE SYNTHESIS GROUP ON DETERMINANTS OF PRETERM/LBW BIRTHS. 2011, Environ. Int., 37, 2011, p. 498.

[26] U.S. Environmental Protection Agency, Extremely Hazardous Substances (EHS) Chemical Profiles and Emergency First Aid Guides, 1998, U.S. Government Printing Office: Washington, D.C.

[27] SETHI, G., BELUM, V.R., MAIBACH, H.I., Sulfuric acid burns, Springer Berlin Heidelberg, Berlin, Heidelberg, 2012, p. 1951.

[28] MILLS, S.W., OKOYE, M.I., Am. J. Foren. Med. Path., 8, no. 3, 1987, p. 252.

[29] TUOMINEN, M., Acta. Odontol. Scand., 49, no. 5, 1991, p. 261.

[30] ULECKIENE, S., GRICIUTE, L., Pathol. Oncol. Res., 3, no. 1, 1997, p. 38.

[31] MULLER, T.L., Kirk-Othmer Encyclopedia of Chemical Technology, 2000.

[32] KIKUCHI, R., Environ. Manage., 27, no. 6, 2001, p. 837.

[33] BRYANT, D., Phosphorus in Environmental Technologies, 2004, p. 1.

[34] NG, N.Y.B., ABDULLAH, A., MILNER, S.M., Eplasty, 15, 2015, p. ic15.

[35] Avantor Performance Materials INC., Phosphorus pentoxide, Center Valley, PA, USA.

[36] RAZZAQUE, M.S., Clin. Sci., 120, no. 3, 2010, p. 91.

[37] KOSE, A., KOSE, B., ACIKALIN, A., GUNAY, N., YILDIRIM, C., Am. J. Emerg. Med., 27, no. 8, 2009, p. 1022.e1.

[38] ZAKY, A., BRADLEY, W.E., LAZRAK, A., ZAFAR, I., DORAN, S., AHMAD, A., WHITE, C.W., DELL'ITALIA, L.J., MATALON, S., AHMAD, S., Physiol. Rep., 3, no. 6, 2015, p. e124391.

[39] WINDER, C., Environ. Res., 85, no. 2, 2001, p. 105.

[40] BASHIR, M.T., ALI, S., BASHIR, A., Pakistan J. Medical Health Sci., 3, 2012, p. 648.

[41] ELMORE, A.R., Int. J. Toxicol., 24, 2005, p. 103.

[42] World Health Organization, Calcium and magnesium in drinking-water: public health significance, World Health Organization, Geneva, 2009, p.

[43] EVANS, K.J., A. GREENBERG, J. Intensive. Care. Med., 20, no. 5, 2005, p. 272.

[44] International Programme on Chemical Safety. 2017. Potassium oxide. International Labour Organization \& World Health Organization. International Chemical Safety Card. ICSC 0769

[45] YOSHIDA, M., MATSUMOTO, Y., SUZUKI, T., NISHIMURA, S., KATO, T., SHIMURA, K., KANEKO, H., TANIWAKI, M., Indian. J. Gastroenterol., 38, no. 5, 2019, p. 460.

[46] WINDER, C., CARMODY, M., Toxicol. Ind. Health., 18, 2002, p. 321.

[47] BONATUCCI, C.A., GOLDFARB, W., SLATER, H., GAISFORD, J.C., J. Burn. Care. Rehabil., 4, no. 4, 1983, p. 282.

[48] CAIN, W.S., JALOWAYSKI, A.A., KLEINMAN, M., LEE, N.S., LEE, B.R., AHN, B.H., MAGRUDER, K., SCHMIDT, R., HILLEN, B.K., WARREN, C.B., CULVER, D., J. Occup. Environ. Hyg., 1, no. 4, 2004, p. 222.

[49] CARPENTER, T.O., DELUCIA, M.C., ZHANG, J.H., BEJNEROWICZ, G., TARTAMELLA, L., DZIURA, J., PETERSEN, K.F., BEFROY, D., COHEN, D., J. Clin. Endocr. Metab., 91, no. 12, 2006, p. 4866. 
[50] TATSUKI, M., MIYAZAWA, R., TOMOMASA, T., ISHIGE, T., NAKAZAWA, T., ARAKAWA, H., World. J. Gastroenterol., 17, no. 6, 2011, p. 779.

[51] KATO, Y., YAMAGUCHI, S., YACHIKU, S., NAKAZONO, S., HORI, J.I., WADA, N., HOU, K., Urology, 63, no. 1, 2004, p. 7.

[52] MANGALAMPALli, B., DUMALA, N., GROVER, P., Regul. Toxicol. Pharm., 90, 2017, p. 170.

[53] Sigma-Aldrich Material Safety Data Sheet - Copper(II) Oxide. Available from: https://www.nwmissouri.edu/naturalsciences/sds/c/Copper\%20II\%20oxide.pdf. [03.06.2021].

[54] BORKOW, G., GABBAY, J., DARDIK, R., EIDELMAN, A.I., LAVIE, Y., GRUNFELD, Y., IKHER, S., HUSZAR, M., ZATCOFF, R.C., MARIKOVSKY, M., Wound. Repair. Regen., 18, no. 2, 2010, p. 266.

[55] SANTA CRUZ BIOTECHNOLOGY Material Safety Data Sheet - Manganese(II) Oxide. Available from: https://datasheets.scbt.com/sc-257692.pdf. [03.06.2021].

[56] CARLISLE, E.M., Silicon, Springer US, Boston, MA, 1984, p. 257-291.

[57] STRATtA, P., CANAVESE, C., MESSUEROTTI, A., FENOGliO, I., FUBINI, B., J. Nephrol., 14, no. 4, 2001, p. 228.

[58] GREENBERG, M.I., WAKSMAN, H., CURTIS, J., Dis. Mon., 53, no. 8, 2007, p. 394.

[59] LEUNG, C.C., YU, I.T.S., CHEN, W., Lancet, 379, no. 9830, 2012, p. 2008.

[60] ALLISON, A.C., HARINGTON, J.S., BIRBECK, M., J. Exp. Med., 124, no. 2, 1966, p. 141.

[61] Elemental Microanalysis Safety Data Sheet - Aluminium Oxide Powder. Available from: https://www.elementalmicroanalysis.com/Downloads/ALUMINIUM\%20OXIDE\%20POWDER.pd f. [03.06.2021].

[62] Spectrum Safety Data Sheet - Ferric Oxide. Available from: https://pimresources.coleparmer.com/sds/80086-85-87-sds.pdf. [03.06.2021].

[63] New Jersey Department Of Health And Senior Services, Hazardous Substance Fact Sheet Chromic oxide. Available from: https://nj.gov/health/eoh/rtkweb/documents/fs/0434.pdf. [03.06.2021].

[64] Fischer Scientific Material Safety Data Sheet - Chromium(III) Oxide. Available from: https://fscimage.fishersci.com/msds/05060.htm. [03.06.2021].

[65] U.S. National Library of Medicine, Arsenic Trioxide. Available from: https://druginfo.nlm.nih.gov/drugportal/name/arsenic\%20trioxide. [03.06.2021].

[66] U.S. Environmental Protection Agenc, Interim Acute Exposure Guideline Levels (AEGLs) Arsenic Trioxide. Available from: https://www.epa.gov/sites/production/files/201409/documents/arsenictrioxide_interim_nd_dec2008_c.pdf. [03.06.2021].

[67] OSTAFE, V., STEVANOVIC, Z., POPOVICI STURZA, C., ISVORAN, A., New Front. Chem., 30, no. 1, 2021, p.1.

Citation: Boros B.V., Roman D.L., Ostafe V., Marković R., Gardić V., Stevanović Z., Isvoran A., The effects on human health of non-metallic, semimetals and heavy metals compounds generated by mining activities along the Serbian-Romanian border, Rom. J. Ecol. Environ. Chem., 2021, 3, no. 1, pp. 61-70.

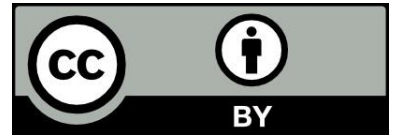

(C) 2021 by the authors. This article is an open access article distributed under the terms and conditions of the Creative Commons Attribution (CC BY) license (http://creativecommons.Org/licenses/by/4.0/). 